\title{
Quadrature conductivity: A quantitative indicator of bacterial abundance in porous media
}

\author{
Chi Zhang ${ }^{1}$, André Revil ${ }^{2}$, Yoshiko Fujita ${ }^{3}$, Junko Munakata-Marr ${ }^{4}$, and George Redden ${ }^{5}$
}

\begin{abstract}
The abundance and growth stages of bacteria in subsurface porous media affect the concentrations and distributions of charged species within the solid-solution interfaces. Therefore, spectral induced polarization (SIP) measurements can be used to monitor changes in bacterial biomass and growth stage. Our goal was to gain a better understanding of the SIP response of bacteria present in a porous material. Bacterial cell surfaces possess an electric double layer and therefore become polarized in an electric field. We performed SIP measurements over the frequency range of $0.1-1 \mathrm{kHz}$ on cell suspensions alone and cell suspensions mixed with sand at four pore water conductivities. We used Zymomonas mobilis at four different cell densities (including the background). The quadrature conductivity spectra
\end{abstract}

exhibited two peaks, one around $0.05-0.10 \mathrm{~Hz}$ and the other around 1-10 Hz. Because SIP measurements on bacterial suspensions are typically made at frequencies greater than $1 \mathrm{~Hz}$, these peaks have not been previously reported. In the bacterial suspensions in growth medium, the quadrature conductivity at peak I was linearly proportional to the density of the bacteria. For the case of the suspensions mixed with sands, we observed that peak II presented a smaller increase in the quadrature conductivity with the cell density. A comparison of the experiments with and without sand grains illustrated the effect of the porous medium on the overall quadrature conductivity response (decrease in the amplitude and shift of the peaks to the lower frequencies). Our results indicate that for a given porous medium, time-lapse SIP has potential for monitoring changes in bacterial abundance within porous media.

\section{INTRODUCTION}

Bacteria play an important role in environmental applications such as the remediation of nitrates and organic contaminants in groundwater (Toledo et al., 2006), the bioleaching of ores (e.g., Eisele and Gabby, 2014), managed aquifer recharge (Cockett and Pidlisecky, 2014), and the natural attenuation of leachates from landfills (Naudet et al., 2004). In addition, there is a growing interest in understanding the role of indigenous anaerobic bacteria in biodegraded oil fields (Grabowski et al., 2005) as well as in situ bioaugmentation and biostimulation of contaminated groundwater (Ginn et al., 2002). In addition, in microbial-enhanced oil recovery (in which microorgan- isms are injected into a reservoir), quantitative information on bacterial abundance and spatiotemporal knowledge of microorganism locations are essential (Heenan et al., 2013).

Minimally invasive (for instance involving shallow wells for crosswell tomography) diagnostic techniques are needed to provide nearly real time information of the spatiotemporal distribution of bacteria in porous media for calibrating and validating predictive models and for monitoring bacterial growth in situ. In the last decade, the remote detection of processes associated with bacterial activity in porous media has been demonstrated using various active and passive geophysical methods including electric and seismic techniques (e.g., Naudet and Revil, 2005; Ntarlagiannis et al.,

Manuscript received by the Editor 10 March 2014; revised manuscript received 8 July 2014; published online 16 September 2014.

${ }^{1}$ Formerly Colorado School of Mines, Department of Geophysics, Golden, Colorado, USA and Idaho National Laboratories, Idaho Falls, Idaho, USA; presently Rutgers University, Department of Earth and Environmental Science, Newark, New Jersey, USA. E-mail: chi.zhang15@gmail.com.

${ }^{2}$ Colorado School of Mines, Department of Geophysics, Golden, Colorado, USA and Université de Savoie, ISTerre, CNRS, UMR, Le Bourget du Lac, France. E-mail: arevil@mines.edu.

${ }^{3}$ Idaho National Laboratory, Idaho Falls, Idaho, USA and University of Copenhagen, Department of Chemistry, Nanogeoscience Group, Copenhagen, Denmark. E-mail: yfujita@nano.ku.dk.

${ }^{4}$ Colorado School of Mines, Department of Civil and Environmental Engineering, Golden, Colorado, USA. E-mail: jmmarr@mines.edu.

${ }^{5}$ University of Copenhagen, Department of Chemistry, Nanogeoscience Group, Copenhagen, Denmark. E-mail: gredden@alumni.stanford.edu.

(C) 2014 Society of Exploration Geophysicists. All rights reserved. 
2005b; Williams et al., 2005; Davis et al., 2006; Linde and Revil, 2007; Personna et al., 2008; Zhang et al., 2010). Under some circumstances, bacterial activity can also be detected passively using the self-potential method (Naudet et al., 2003, 2004; Revil et al., 2010; Risgaard-Petersen et al., 2012, 2014). This passive technique is used to detect remotely the occurrence of electric current associated with the displacement of electrons through biotic electronic conductors. It is very similar, in essence, to the electroencephalographic method used to detect remotely the electric current generated by the opening of ionic channels at the synapses between neurons (Grech et al., 2008). Bacteria can form biogeobatteries in the subsurface of the Earth. In areas of strong redox potential gradients, their activity can be therefore remotely detected using the resulting electric field (Revil et al., 2010). However, this method does not provide any information regarding the density of bacterial populations in porous media and its changes over time.

Induced polarization is an active geophysical method investigating the reversible storage of electric charges in porous media. In other

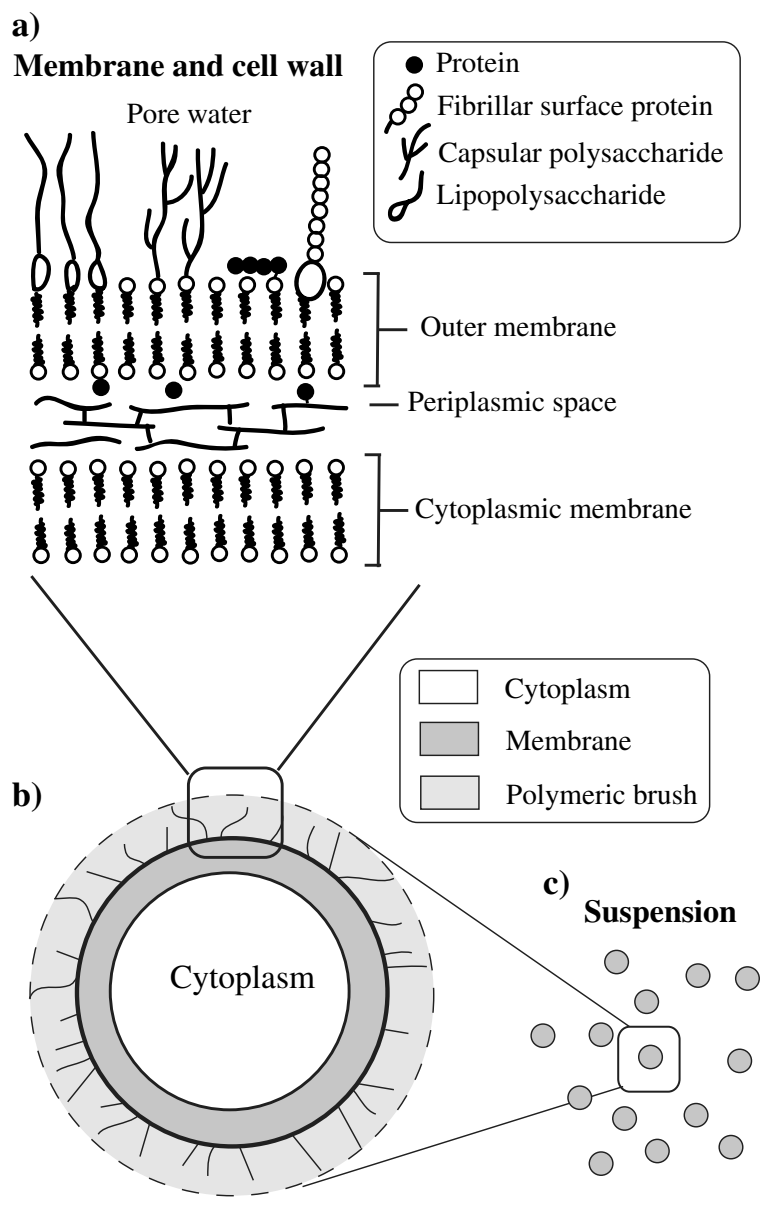

Gram-negative bacteria

Figure 1. Conceptual model of Gram-negative bacteria. (a) The surface of Gram-negative bacteria with the membrane. This surface has a negative charge at a $\mathrm{pH}$ of greater than 3. (b) A single cell is considered to consist of the polymeric brush coating the surface of the bacteria, the membrane, and the cytoplasm. (c) We are interested in the properties of a suspension of bacteria in which each bacterium has an electric double layer comprising the Stern and diffuse layers. words, it investigates the capacitance of porous media at low frequencies of the exciting electric field (typically between $1 \mathrm{mHz}$ and $10 \mathrm{kHz}$ ). Recent reviews on this geophysical method, the associated mechanisms, and applications in environmental geosciences can be found in Kemna et al. (2012) and Revil et al. (2012b). The in-phase component of the complex conductivity describes the electromigration of the charge carriers in the material, whereas its quadrature component describes the polarization. The induced polarization method has been qualitatively shown to be sensitive to the presence of bacteria in porous media (Abdel Aal et al., 2004, 2010; Ntarlagiannis et al., 2005a; Davis et al., 2006; Albrecht et al., 2011; Revil et al., 2012a; Zhang et al., 2012). The low-frequency polarization of bacteria in porous media has been recently modeled by Revil et al. (2012a) with a special emphasis on Gram-positive bacteria. Revil et al. (2012a) use a polarization model of the double layer surrounding the bacterial cells. They upscaled their results to a representative elementary volume of a porous material with a composite model taking into account the presence of the bacteria and the grains.

In the present study, we investigated the polarization properties of a typical Gram-negative bacteria Zymomonas mobilis whose surface is surrounded by an electric double layer. This organism was selected for the experiments because it produces ethanol from glucose, so that neither the substrate nor product is charged (avoiding ion effects on electric conductivity; see Gunasekaran et al., 1986). In addition, precipitation of mineral products, which could impact porosity or affect the formation factor, was not expected as a result of its metabolism. We investigated the spectral induced polarization (SIP) signatures of colloidal suspensions of this bacterium in growth media. Then, we mixed the cell suspensions with sand grains. Our goals were (1) to provide clear data showing the influence of the abundance of the bacteria upon the quadrature conductivity and (2) to determine if the relationship between the quadrature conductivity and the bacterial cell density in porous media could be quantitatively defined.

\section{THEORETICAL BACKGROUND}

\section{General considerations}

Bacterial cells consist of a cytoplasm enclosed by an insulating membrane (Figure 1). Generally speaking, at $\mathrm{pH}$ values greater than $3-4$, the cell external surface or cell wall is negatively charged as a result of protonation/deprotonation of surface ionizable groups (amine groups, carboxylic acid groups, hydroxyl groups, phosphodiesters, and phosphomonoester; see Figure 2a) (e.g., Willis, 1980; Revil et al., 2012a). This negative charge on the cell surface is compensated by cations that are either sorbed on the bacterial surface (Stern layer) or present in the diffuse layer (Figure $2 b$ ).

Under an oscillating electric field at low frequencies $(<100 \mathrm{kHz})$, the electric double layer of bacteria can become polarized. Revil et al. (2012a) provide a model of this polarization, which is known as $\alpha$-polarization in colloidal chemistry (e.g., Foster and Schwan, 1989). In the next sections, we will consider three cases of polarization: (1) a hypothetical bacterial colloidal suspension in a brine solution (Figure 3a), (2) a suspension of bacteria in a growth solution (called the reconstitution medium (RM); see Figure $3 \mathrm{~b}$ ) and (3) a mixture of the (bacterial + RM) colloidal suspension in the pore space between sand grains (Figure $3 \mathrm{c}$ ). The model we use below is valid for dilute or concentrated suspensions and for low and high porosities. For instance, it has been used successfully to under- 
stand the complex conductivity of low-porosity gas shales by Revil et al. (2013) and Woodruff et al. (2014).

\section{Low-frequency polarization of a colloidal suspension of bacteria}

We summarize below the model of Revil et al. (2012a) for a suspension of bacteria (Figure 3a), focusing on the relationship between the magnitude of the quadrature conductivity and the bacterial abundance, rather than modeling the bell-shape frequency dependence of the quadrature conductivity. The complex conductivity of the bacteria is represented by $\sigma_{B}{ }^{*}$. The in-phase (real) component is related to electromigration of the charge carriers occurring in the bulk pore water and in the diffuse layer surrounding the surface of the bacteria (Figure 2b). The quadrature (imaginary) conductivity is related to the polarization of the Stern layer shown in Figure 2b. The in-phase and quadrature conductivity of a suspension of bacteria are given by

$$
\sigma_{B}{ }^{*}=\sigma_{B}{ }^{\prime}+i \sigma_{B}{ }^{\prime \prime},
$$

where

$$
\sigma_{B}{ }^{\prime} \approx \sigma_{w}+\bar{C}_{B} \bar{V}_{B} \rho_{B}(1-f) \beta_{(+)} \mathrm{CEC}_{B}
$$

and a)

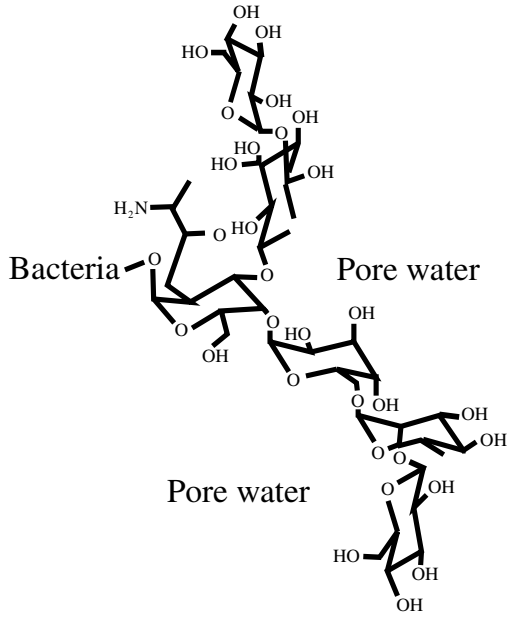

b)

Sketch of the double layer

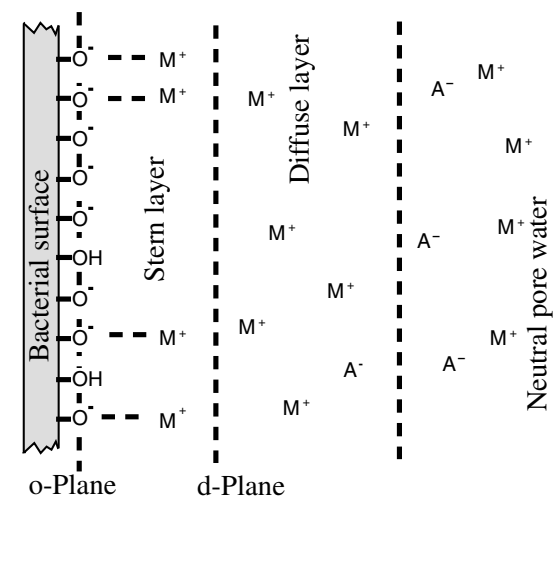

Figure 2. Structure of the electric double layer at the surface of a bacterium. (a) Typical organic molecule at the surface of Gram-negative bacteria (lipopolysaccharide component of the cell wall) showing ionizable groups $>\mathrm{OH}$ and $>\mathrm{NH}_{2}$ in their uncharged forms. (b) Structure of the electric double layer showing the distinction between the Stern layer of weakly sorbed counterions and the diffuse layer. The symbol $\mathrm{M}^{+}$represents a metal cation, whereas $\mathrm{A}^{-}$represents an anion. a)

Suspension bacteria

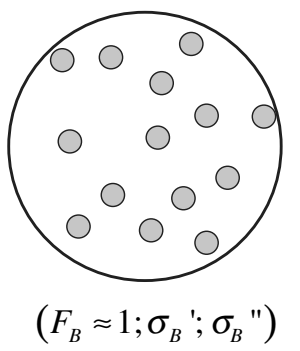

b)

Suspension (bacteria + RM)

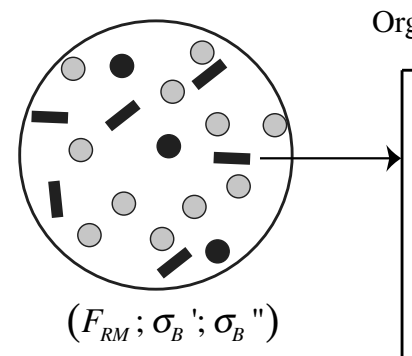

Organic molecules in RM<smiles>COC(=O)C(N)CCC(=O)O</smiles><smiles>O=C(O)CCCC1SC[C@H]2NC(=O)N[C@H]12</smiles>

Glutamic acid<smiles>NC(CCC(=O)O)C(=O)O</smiles>

Glucose<smiles>O=CC(O)C(O)C(O)CO</smiles>

+ yeast extracts c)

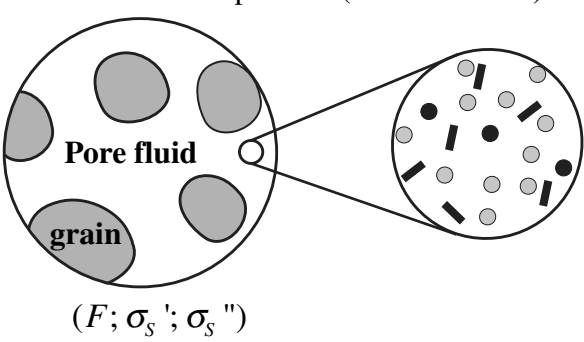

Figure 3. Representative elementary volumes of the suspensions and porous media. (a) Colloidal suspension of bacteria. (b) Colloidal suspension of bacteria with the RM including (black) all the nutrients in the suspension (for a dilute suspension of bacteria, the formation factor associated with the bacteria is equal to 1 ). These nutrients include various large organic molecules and yeast extracts. This soup of organic molecules and bacteria is characterized by its own formation factor $F_{\mathrm{RM}} \approx 1$ and porosity $(\approx 1)$. (c) Granular material with its pore fluid, which can be either an electrolyte like $\mathrm{NaCl}$ or $\mathrm{KCl}$ or the colloidal $\mathrm{RM}$ with or without the bacteria. 


$$
\sigma_{B}^{\prime \prime} \approx-\bar{C}_{B} \bar{V}_{B} \rho_{B} f \beta_{(+)}^{S} \mathrm{CEC}_{B},
$$

and where $i\left(i^{2}=-1\right)$ denotes the pure imaginary number, $f$ denotes the fraction of the counterions in the Stern layer around the bacteria and therefore $(1-f)$ denotes the fraction of counterions in the diffuse layer; $\beta_{(+)}$and $\beta_{(+)}^{S}$ (in $\mathrm{m}^{2} \mathrm{~s}^{-1} \mathrm{~V}^{-1}$ ) denote the mobility of the counterions in the diffuse and Stern layers, respectively; $\sigma_{w}\left(\mathrm{~S} \mathrm{~m}^{-1}\right)$ denotes the conductivity of the pore water, $\rho_{B}\left(\mathrm{~kg} \mathrm{~m}^{-3}\right)$ is the mass density of the bacteria; $\bar{C}_{B}=N_{B} / V$ denotes the number of bacteria per unit pore volume (expressed usually in cell $\mathrm{m}^{-3}$ in SI units but generally in cell $\mathrm{mL}^{-1}$ ) where $N_{B}$ denotes the total number of bacteria and $V$ is the volume of the colloidal suspension; $\bar{V}_{B}$ is the specific volume of a bacterium; and $\mathrm{CEC}_{B}\left(\mathrm{C} \mathrm{kg}^{-1}\right)$ is the cation exchange capacity (CEC) of the bacteria. This CEC represents, at a given $\mathrm{pH}$ and solution composition, the number of exchangeable sites on the external wall of the bacteria (see Revil et al. [2012a] for a collection of references regarding the CEC of bacteria).

The second term of equation 2 corresponds to the conductivity of the bacteria themselves (the surface conductivity of the bacteria $\sigma_{B}^{S} /$ and the conductivity of a single bacterium is given by $\sigma_{B}=(1-f) \beta_{(+)} \rho_{B} \mathrm{CEC}_{B}$ ) (Revil et al., 2012a). Note that alternatively, we could express the conductivity of a bacterium in terms of its radius and its surface conductance produced by the diffuse layer (see, for instance, Revil and Skold [2011] for sand grains). Both approaches are valid, but the CEC is usually the reported parameter describing the electrochemical properties of the bacteria surface, not the surface conductance. Equation 3 indicates that the quadrature conductivity of the suspension of bacteria is directly proportional to the concentration of the bacteria $\bar{C}_{B}$, an intuitive result. The mobility of the counterions (cations) populating the Stern layer is typically $\beta_{(+)}^{S} \approx(4.7 \pm 0.8) \times 10^{-10} \mathrm{~m}^{2} \mathrm{~s}^{-1} \mathrm{~V}^{-1}$ at $25^{\circ} \mathrm{C}$ according to Revil et al. (2012a), whereas the mobility of the counterions in the diffuse layer $\beta_{(+)}$is equal to the mobility of the same ions in the bulk pore water.

Revil et al. (2012a) conclude that all the CECs of Gram-negative bacteria contribute to surface conductivity and quadrature conductivity and are likely to be distinctly different from the underlying substrate mineral, especially if time-lapse measurements are used to distinguish between the time-dependent effect associated with the growth of bacteria from the static value associated with the mineral grains. In contrast, only a fraction of the CEC of Gram-positive bacteria contributes to surface conductivity and polarization. Indeed, according to the surface speciation of Gram-positive bacteria (see an extensive discussion in Revil et al., 2012a), this behavior is due to the $\mathrm{pH}$ dependence of the amino surface groups of the protein and peptidoglycan molecules on the surface of the Gram-positive bacteria. These sites can accept counterions only at $\mathrm{pH}>8$. On Gram-negative cells, lipopolysaccharides replace peptidoglycan molecules. They contain charged phosphate and carboxyl groups but no amino surface groups.

In general, for Gram-negative bacteria, the value of $\mathrm{CEC}_{B}$ is in the order of $1.8 \mathrm{mMol} \mathrm{g}^{-1}$ (see Table 1 of Revil et al., 2012a) but can vary considerably between species. We have not been able to find a CEC value specific to Z. mobilis in the literature. In the following, we will see that our data are consistent with assuming $\mathrm{CEC}_{B} \approx 2.0 \mathrm{mMol} \mathrm{g}^{-1}$ for $Z$. mobilis therefore close to the mean value reported for Gram-negative bacteria in Revil et al. (2012a). The mass density of active and healthy bacteria is from
$\rho_{B} \sim 1010$ to $1020 \mathrm{~kg} \mathrm{~m}^{-3}$ (Bratbak and Dundas, 1984). Finally, $\bar{V}_{B}$, the volume of a single bacterium, is typically in the range $0.5-2.0 \mu \mathrm{m}^{3}$.

Now, we consider that the previous suspension of bacteria is mixed with the RM. The RM is considered to be a dilute colloidal suspension with its own formation factor $F_{\mathrm{RM}}$, which is close to unity if the suspension is dilute enough (Figure $3 b$ ). Note that high ionic strength may destroy the cell through osmotic shocks. So, the complex conductivity of the RM could be defined as

$$
\sigma_{\mathrm{RM}} * \equiv \sigma_{\mathrm{RM}}^{\prime}+i \sigma_{\mathrm{RM}}{ }^{\prime \prime}=\frac{1}{F_{\mathrm{RM}}} \sigma_{B}{ }^{*} \approx \sigma_{B}{ }^{*} .
$$

Consequently, in our model, the in-phase and quadrature conductivity of the bacteria + RM suspension are those of the suspension of the bacteria itself. The slope of the quadrature conductivity of the suspension (bacteria plus the RM) versus the bacteria concentration can be written as

$$
\sigma_{\mathrm{RM}}^{\prime \prime} \approx-a_{S} \bar{C}_{B}
$$

where

$$
a_{S} \approx \bar{V}_{B} \rho_{B} f \beta_{(+)}^{S} \mathrm{CEC}_{B}
$$

Equation 6 will be verified later in this paper. Taking, for instance, $\beta_{(+)}^{S}=5 \times 10^{-10} \mathrm{~m}^{2} \mathrm{~s}^{-1} \mathrm{~V}^{-1}$ at $25^{\circ} \mathrm{C}, \mathrm{CEC}_{B}=1 \mathrm{~m} \mathrm{Mol} \mathrm{g}^{-1}$ $\left(\approx 10^{5} \mathrm{C} \mathrm{kg}^{-1}\right.$ ), $f=0.8$ (see the discussion of these values in Revil et al., 2012a), $\rho_{B}=10^{3} \mathrm{~kg} \mathrm{~m}^{-3}$, and $\bar{V}_{B}=1.0 \mu \mathrm{m}^{3}\left(10^{-18} \mathrm{~m}^{3}\right)$, we obtain $a_{S}=4.0 \times 10^{-14}$ (in $\mathrm{m} \mathrm{S}^{-1} \mathrm{~mL}$ cell ${ }^{-1}$ ) with $\bar{C}_{B}$ expressed in cells $\mathrm{mL}^{-1}$. For a cell density of $1 \times 10^{9}$ cell $\mathrm{mL}^{-1}$, the quadrature conductivity would be $\sigma_{\mathrm{RM}}{ }^{\prime \prime}=-4.0 \times 10^{-5} \mathrm{~S} \mathrm{~m}^{-1}$. The surface conductivity would be $\sigma_{B}^{S} \prime=\bar{C}_{B} \bar{V}_{B} \rho_{B}(1-f) \beta_{(+)} \mathrm{CEC}_{B}=$ $1.0 \times 10^{-3} \mathrm{~S} \mathrm{~m}^{-1}$. This provides a first-order evaluation of the surface and quadrature conductivities that we can expect in this study.

\section{Polarization of porous materials with bacteria and reconstitution medium solution}

The complex conductivity of a porous material $\sigma *=\sigma^{\prime}+i \sigma^{\prime \prime}$ without the bacteria and/or the RM fluid is given by

$$
\sigma^{*}=\frac{1}{F} \sigma_{w}+\sigma_{g}{ }^{*},
$$

where $F$ denotes the (intrinsic) formation factor of the porous material saturated by an electrolyte $\left(F=\phi^{-m}\right.$ according to Archie's law, where $\varphi$ denotes the connected porosity) and without the bacteria and $\sigma_{g}{ }^{*}={\sigma_{g}}{ }^{\prime}+i \sigma_{g}{ }^{\prime \prime}$ denotes the complex-valued surface conductivity associated with electromigration $\left(\sigma_{g}{ }^{\prime}\right)$ and polarization $\left(\sigma_{g}{ }^{\prime \prime}\right)$ in the electric double layer coating the surface of the mineral grains. Replacing the pore water electrolyte by the suspension of bacterial cells (within the RM suspension) in the porous material is therefore equivalent to replacing $\sigma_{w}$ in equation 7 by the complex conductivity of the suspension $\sigma_{\mathrm{RM}}{ }^{*}$. This yields

$$
\sigma^{*}=\frac{1}{F} \sigma_{\mathrm{RM}}^{*}+\sigma_{g}^{*} .
$$


The in-phase and quadrature conductivity of the porous material with the colloidal suspension as pore water are related to the complex conductivity $\sigma^{*}$ by $\sigma^{*}=\sigma^{\prime}+i \sigma^{\prime \prime}$. Therefore, we have

$$
\sigma^{\prime}=\frac{1}{F}\left(\sigma_{w}+\bar{C}_{B} \bar{V}_{B} \rho_{B}(1-f) \beta_{(+)} \mathrm{CEC}_{B}\right)+\sigma_{g}{ }^{\prime}
$$

and

$$
\sigma^{\prime \prime}=-\frac{1}{F} \bar{C}_{B} \bar{V}_{B} \rho_{B} f \beta_{(+)}^{S} \mathrm{CEC}_{B}+\sigma_{g}{ }^{\prime \prime}
$$

The quadrature conductivity is the sum of the contribution associated with the grains (background polarization) and the contribution associated with the bacteria, dependent on the abundance of the bacteria but affected by the formation factor of the porous material. In other words, the total polarization of the material is not simply the sum of the polarization of the grains and the polarization of the bacteria. The in-phase conductivity can be written as

$$
\sigma^{\prime}=\frac{1}{F} \sigma_{w}+\sigma_{S}^{\prime}
$$

where $\sigma_{S}{ }^{\prime}$ denotes the total surface conductivity of the porous material including the effect of the bacteria and the mineral grains as

$$
\sigma_{S}{ }^{\prime}=\frac{1}{F}\left(\bar{C}_{B} \bar{V}_{B} \rho_{B}(1-f) \beta_{(+)} \mathrm{CEC}_{B}\right)+\sigma_{g}{ }^{\prime} .
$$

The in-phase conductivity is not expected to be strongly dependent on the bacterial concentration because the surface conductivity of the bacteria is expected to be small with respect to the conductivity of the pore water $\sigma_{w}$. In contrast, the quadrature conductivity is expected to be directly proportional to the concentration of bacteria with a small contribution of the background quadrature conductivity (Revil et al., 2012a). We will investigate below what is the relative contribution of the quadrature conductivity due to the bacteria with respect to the grains. As discussed above, the slope of the quadrature conductivity versus the bacterial concentration is given by $a_{S}$ for a suspension. In the case of a porous material, it is given by the following expression:

$$
\sigma^{\prime \prime}=-\left(a \bar{C}_{B}+b\right)
$$

where

$$
a=\frac{1}{F} \bar{V}_{B} \rho_{B} f \beta_{(+)}^{S} \mathrm{CEC}_{B}
$$

and

$$
b=-\sigma_{g}{ }^{\prime \prime} .
$$

Therefore, according to our model, the slope of the trend between the quadrature conductivity and the concentration of bacteria will depend on the formation factor of the material and the CEC of the bacteria. We expect therefore to have smaller sensitivity to change in the concentration of bacteria when the porosity decreases and the formation factor increases.

\section{MATERIAL AND METHODS}

\section{Bacterial culture preparation}

Z. mobilis is a rod-shaped Gram-negative bacterium with an average length of about $2.5 \mu \mathrm{m}$ that grows optimally under anaerobic conditions but is an aerotolerant, motile fermenter with a highly active ethanol fermentation pathway (Grube et al., 2012). The optimum $\mathrm{pH}$ range for the growth of $\mathrm{Z}$. mobilis is 5.5-7.0 and the optimum temperature range is $25-31^{\circ} \mathrm{C}$ (Gunasekaran et al., 1986). Cultures of Z. mobilis (strain ZM4 [CP4]/ATCC, American Type Culture Collection, \#31821) were started by using $-80^{\circ} \mathrm{C} \mathrm{Z}$. mobilis stocks as $9 \%$ inocula for $5 \mathrm{~mL}$ of a defined RM based on ATCC medium 1341, which included glucose $20 \mathrm{~g} \mathrm{~L}^{-1}$, yeast extract $10 \mathrm{~g} \mathrm{~L}^{-1}$, and $\mathrm{KH}_{2} \mathrm{PO}_{4} 2 \mathrm{~g} \mathrm{~L}^{-1}$ (pH adjusted to 6). The electric conductivity of this original RM suspension was $0.277 \mathrm{~S} \mathrm{~m}^{-1}$ (initial conductivity of the medium with the $9 \%$ inoculum of cells). After $24 \mathrm{~h}$ of growth, this original culture was used as $9 \%$ inocula for $100 \mathrm{~mL}$ "production" cultures. The production cultures were then incubated in 250-mL Erlenmeyer flasks with foam stoppers (allowing air to circulate) at $30^{\circ} \mathrm{C}$ in a Fisher Isotemp incubator without shaking. The purity of the cell cultures was checked regularly by plating on Luria Bertani agar.

The growth curves of optical density at $600 \mathrm{~nm}\left(\mathrm{OD}_{600}\right)$ versus incubation time for $Z$. mobilis in RM from two tests are shown in Figure 4. The $\mathrm{OD}_{600}$ measurements were made using a Genesys 10 Vis spectrophotometer. Z. mobilis reached the stationary phase and a maximum $\mathrm{OD}_{600}(\mathrm{OD}=0.787)$ only after $\sim 8.5 \mathrm{~h}$ (Figure 4$)$, remained stable until $\sim 18.5 \mathrm{~h}$, and then the OD started to drop until the end of the measurement period (1500 min). The correlation of $\mathrm{OD}_{600}$ with actual cell numbers was determined by performing

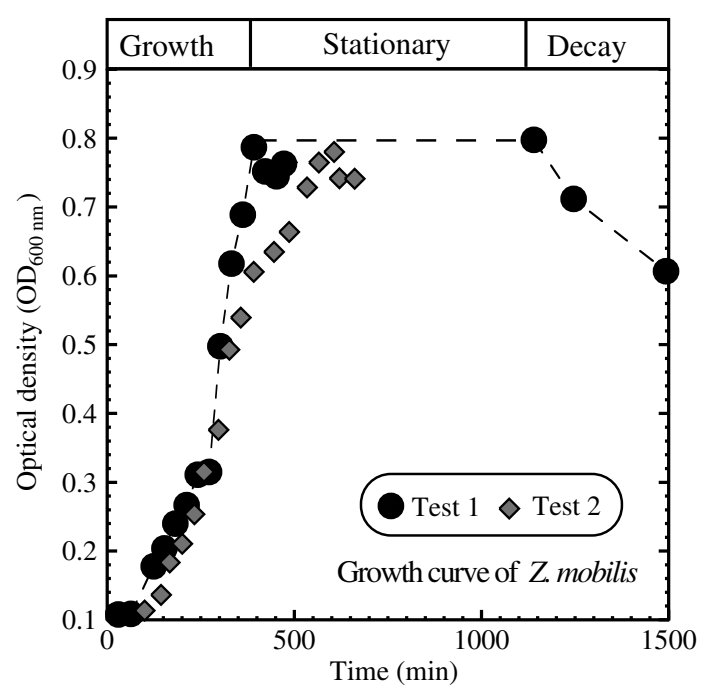

Figure 4. Growth curves. Plot for the growth of Z. mobilis measured at $30^{\circ} \mathrm{C}$ in $\mathrm{RM}$ showing the growth, stationary, and decay phases. Z. mobilis is characterized by a very fast growth rate. The two tests demonstrate the repeatability of the measurements. To maintain consistency across experiments in our study, we harvested cells in the growth phase of the curve for SIP measurements. 
direct microscopic counts using a Petroff-Hausser counting chamber $\left(1 / 400 \mathrm{~mm}^{2}, 0.02 \mathrm{~mm}\right)$ under phase contrast microscopy. The culture grown for $12 \mathrm{~h}$ (test 1, Figure 4) was collected and diluted with $0.85 \% \mathrm{NaCl}$ solution for cell counting. Dilutions from the initial inocula showed a linear relationship between the OD measurements and the number of cells (Figure 5). To construct the calibration curve, seven observed ODs (the minimum is 0.177 , and the maximum is 0.752 ) were chosen and the corresponding calculated cell numbers were plotted against the OD. A linear relationship exists between the cell number (density) and $\mathrm{OD}_{600}$ up to approximately $\mathrm{OD}_{600}=0.6$ (Figure 5). Then, the cultures were diluted in RM for three desired OD (three different dilutions) for SIP measurements. A second test (test 2, Figure 4) was performed to check the reproducibility of the growing phase.

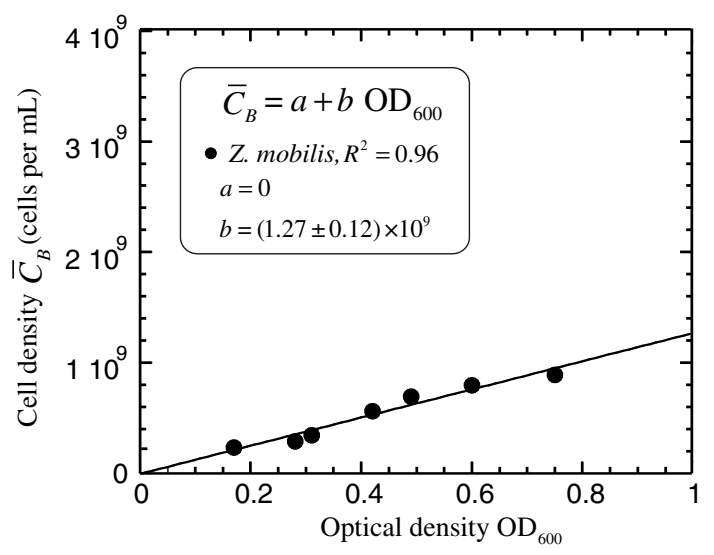

Figure 5. Plot of the observed $\mathrm{OD}_{600}$ against the direct count cell numbers per milliliter and associated linear regression fit for Z. mobilis.
The bacterial concentrations were estimated from the plot of cell numbers per milliliter against the corresponding $\mathrm{OD}_{600}$ readings (Figure 5). Three cell densities of $0.41 \times 10^{9}, 0.35 \times 10^{9}$, and $0.23 \times 10^{9}$ cells $\mathrm{mL}^{-1}$ were used in the SIP experiments, and the corresponding fluid conductivities of these three cell suspensions were $0.025,0.0165$, and $0.0118 \mathrm{~S} \mathrm{~m}^{-1}$. All samples were suspended in phosphate buffer at $\mathrm{pH} 5.75$ prior to use in the experiments with sand.

\section{Experimental procedure for induced polarization}

The equipment used for the SIP measurement is shown in Figure 6. One hundred twenty-five $\mathrm{ml}$ wide-mouth cylindrical plastic jars (VWR polypropylene autoclavable bottles with screw closures, diameter: $5.02 \mathrm{~cm}$ ) were modified for use as the sample holders (Figure $6 \mathrm{a}$ and $6 \mathrm{~b}$ ). Four pellets of biomedical, nonpolarizing $\mathrm{Ag}-\mathrm{AgCl}$ electrodes with a spacing of $1.5 \mathrm{~cm}$ from each other were installed vertically along one side of the jar. The outer two electrodes (A and B) were used for current injection/retrieval, and the two middle electrodes ( $\mathrm{M}$ and $\mathrm{N}$ ) were used to record the potential (Wenner array, Figure 6a). For a Wenner array in a half-space, the geometric factor is given by $g=2 \pi s$, where $s$ is the distance between the electrodes. In our case, this yields $g=9.4 \mathrm{~cm}$ for an ideal half-space electrode array. We performed a calibration of the geometric factor of the cell with a $\mathrm{KCl}$ salt solution at a known conductivity $\left(0.025 \mathrm{~S} \mathrm{~m}^{-1}\right)$, and the calibrated geometric factor was $g=5.6 \mathrm{~cm}$, which is the geometric factor used in our calculations. This shows how important such calibration is to get the correct value of the geometric factor.

To prevent electrode polarization that could obscure the polarization contribution from the bacteria, we use a four-electrode approach separating the voltage electrodes from the current electrodes. Only the current electrodes would display polarization because of the a)

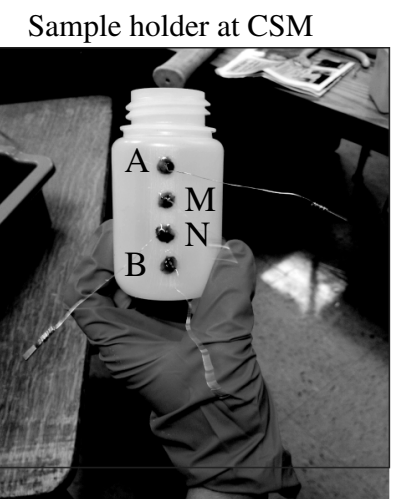

b)

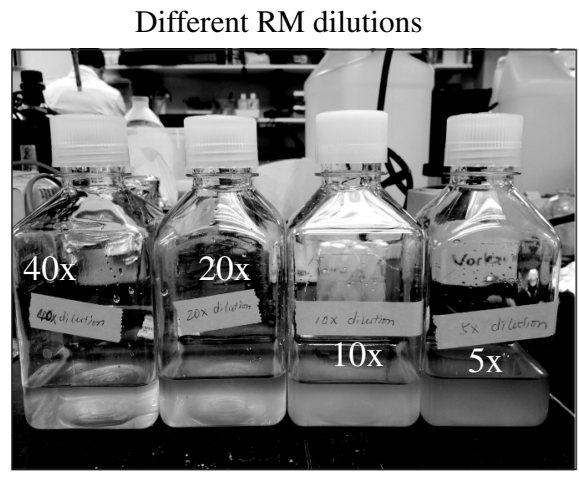

A, B Current electrodes, M, N Potential electrodes

c)

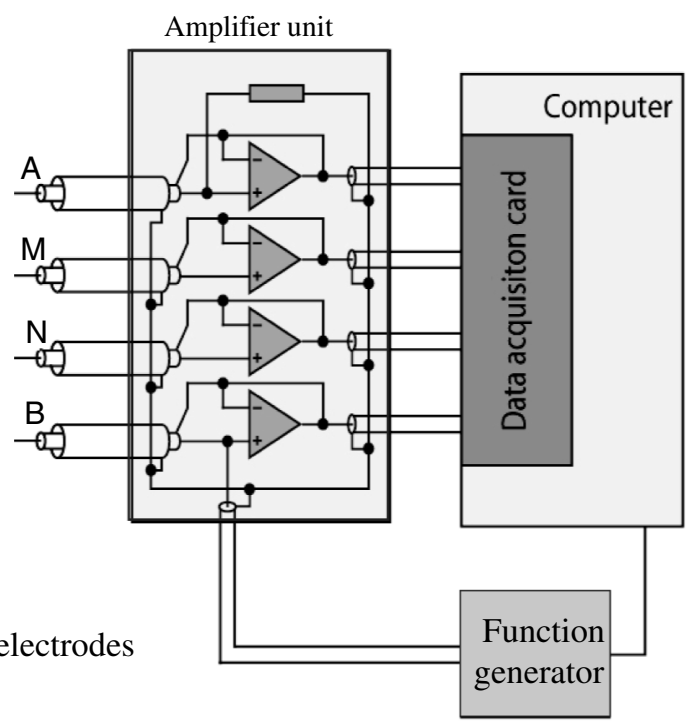

Figure 6. Experimental setup used for the SIP measurements. (a) Sample holder used with the ZEL-SIP04-V02 impedance meter showing the position of the $4 \mathrm{Ag} / \mathrm{AgCl}$ electrodes (Wenner array). (b) $\mathrm{RM}$ solutions with bacteria at four different dilutions (the most concentrated is on the right side). The geometric factors for the sample holder were calibrated using a solution of known conductivity. The factors $40 \times$ to $5 \times$ denote the different dilutions as explained in the main text. (c) ZEL-SIP04-V02 impedance meter. 
change of the nature of the charge carriers at their surface (Kemna, 2000). Several benchmark tests of the impedance meter used in this study can be found in Revil and Skold (2011). The complex conductivity response obtained with water alone, as expected, does not display polarization effects (see Figure 5 of Revil and Skold, 2011).

The SIP measurements for the Z. mobilis experiments were taken using the ZEL-SIP04-V02 impedance meter (Zimmermann et al. [2008], Figure 6c). The accuracy on the phase is $0.1 \mathrm{mrad}$ below $100 \mathrm{~Hz}$ (Zimmermann et al., 2008). The data acquisition system can operate in the frequency range from $1 \mathrm{mHz}$ to $45 \mathrm{kHz}$ with a phase accuracy of $0.1 \mathrm{mrad}$ below $100 \mathrm{~Hz}$ (see Revil and Skold [2011] for various benchmark tests, including tests performed with electric circuits with a known resistance in parallel with a known capacitance).

For the SIP measurements, $125 \mathrm{~mL}$ of bacterial suspension at different cell concentrations was prepared, and each measurement was taken from $0.1 \mathrm{~Hz}$ to $10 \mathrm{kHz}$ with $2 \mathrm{~V}$ input voltage. The time that would have been required to do low-frequency measurements, below $0.05 \mathrm{~Hz}$, was too long with respect to the risk of lysis of the cells. The $\mathrm{pH}$ and fluid conductivity of each cell suspension sample were measured before and after the SIP measurements to make sure the physicochemical properties of the suspension remained the same. Then, $180 \mathrm{~g}$ of \#70 autoclaved silica sand (physical properties provided in Table 1) was gently added to the $62.5 \mathrm{~mL}$ of each bacterial suspension sample to fill the bottles. We use a wet packing procedure to avoid trapping air bubbles and to facilitate homogeneous distribution of the sand without damaging the cells. Constant and gentle tapping on the container was applied during the introduction of the mixture of bacterial suspension and sand into the sample holders. The total volume of saturated sands and bacterial suspension was calculated and recorded for each packing. The SIP measurements were conducted at room temperature $\left(21 \pm 2^{\circ} \mathrm{C}\right)$ on the bacteria and sand mixtures.

\section{Control experiments}

We performed two sets of control experiments. In the first set of control experiments, the complex conductivity (in-phase and quadrature conductivity) of the sand was determined using $\mathrm{NaCl}$ solutions. The second set of control experiments was conducted using the same growth medium (RM) used for the biotic experiments but in the absence of cells. These control samples were incubated in the isothermal chamber at $30^{\circ} \mathrm{C}$ for the same time as for the cell samples.

\section{EXPERIMENTAL RESULTS}

\section{Control experiments}

The results of the control experiments with the $\mathrm{NaCl}$ solutions are shown in Figure $7 \mathrm{a}$ and $7 \mathrm{~b}$ and with the RM solution without the cells in Figure $7 \mathrm{c}$ and $7 \mathrm{~d}$. The electric conductivity of the RM suspension indicates a formation factor for the RM suspension of $F_{\mathrm{RM}}=1.1$ (not shown); therefore, it is very close to the value for an infinite dilution (1.0). The electric conductivity of the sand with the $\mathrm{NaCl}$ solutions or the RM colloidal suspensions (no bacteria) at the four dilutions of the initial RM solution yields a formation factor of $F=3.7-3.8$ (Figure 7a and 7c and reported in Table 1). The pore water conductivities of the RM solutions are

Table 1. Properties of the sand.

\begin{tabular}{lc}
\hline Properties & Sand grains \\
\hline Material & Silica \\
Porosity $\phi$ & $0.41^{3}$ \\
Grain size $d_{50}$ & $200 \mu \mathrm{m}$ \\
Formation factor $F$ & $3.7 \pm 0.1^{3}$ \\
Hydraulic conductivity $K s$ & $1.4 \times 10^{-4} \mathrm{~m} \mathrm{~s}^{-13}$ \\
Surface conductivity, ${ }^{1} \sigma_{g}{ }^{\prime}$ & $1.2 \times 10^{-4} \mathrm{~S} \mathrm{~m}^{-1}$ \\
${ }^{2}$ Quadrature conductivity, ${ }^{2} \sigma_{g}{ }^{\prime \prime}$ & $-\left(0.5-1.0 \times 10^{-5} \mathrm{~S} \mathrm{~m}^{-1}\right)$ \\
\hline
\end{tabular}

${ }^{1}$ Bolève et al. (2007) for similar silica materials in terms of grain diameter.

${ }^{2}$ At $0.1 \mathrm{~Hz}$.

${ }^{3}$ From Ikard et al. (2012). a)

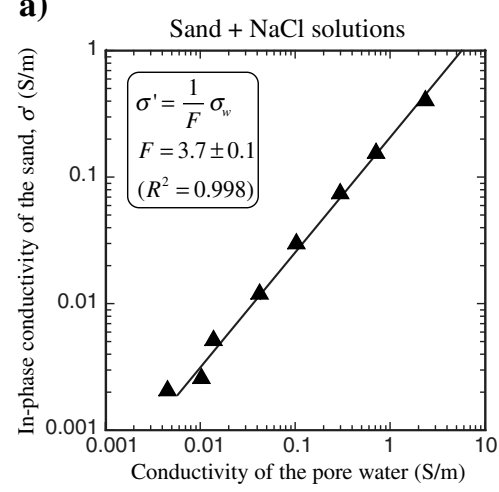

c)

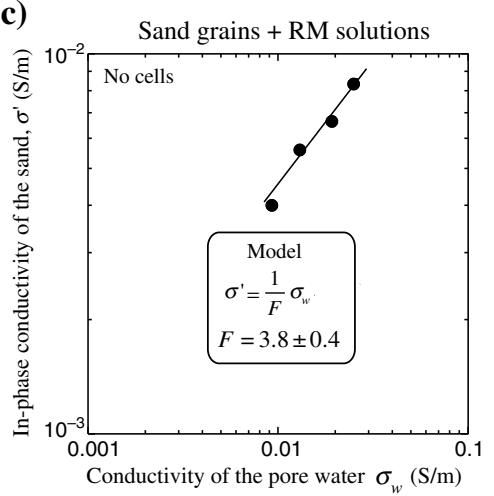

b)

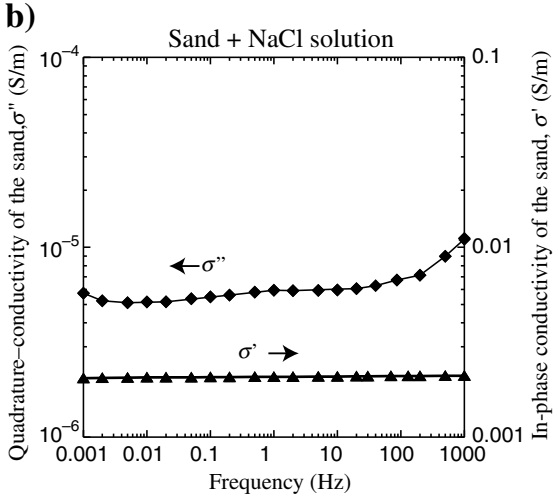

d)

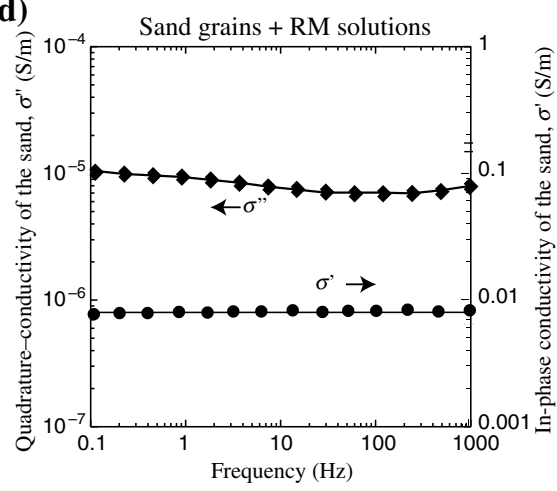

Figure 7. Control experiments: (a) Direct determination of the intrinsic formation factor $F=3.7$ for the sand saturated by a $\mathrm{NaCl}$ solution. (b). In-phase and quadrature conductivities versus frequency for the sand saturated by an $\mathrm{NaCl}$ solution $\left(0.0075 \mathrm{~S} \mathrm{~m}^{-1}\right.$ at $25^{\circ} \mathrm{C}, \mathrm{pH}=7.1$ ). (c) In-phase conductivity versus pore water conductivity for the sand saturated with the RM solution. (d) In-phase and quadrature conductivities versus frequency for the sand saturated by the RM solution. 
reported in Table 2. The background quadrature conductivity for the sand filled with the RM colloidal suspensions without the cells is $-0.8 \pm 0.2 \times 10^{-5} \mathrm{~S} \mathrm{~m}^{-1}$, which corresponds to the quadrature conductivity of the sand grains without the cells $\sigma_{g}{ }^{\prime \prime}$ (Figure $7 \mathrm{~b}$ and $7 \mathrm{~d}$, Table 1). These data provide baselines (background inphase and quadrature conductivities) for the following experiments that will show the effect of the bacteria on the complex conductivity response.

\section{Polarization of suspensions of bacteria}

We now describe the results of the biotic experiments starting with the suspensions of bacterial cells. Figure $8 \mathrm{a}-8 \mathrm{c}$ shows the quadrature conductivity whereas Figure $8 d$ shows the in-phase conductivity data for $Z$. mobilis colloidal suspensions at three different

Table 2. Control experiments.

\begin{tabular}{lcc}
\hline Control & $\mathrm{OD}_{600}$ & $\sigma_{w}\left(\mathrm{~S} \mathrm{~m}^{-1}\right)$ \\
\hline 1 & 0.338 & 0.0250 \\
2 & 0.294 & 0.0192 \\
3 & 0.189 & 0.0130 \\
4 & 0.200 & 0.0093 \\
\hline
\end{tabular}

a)

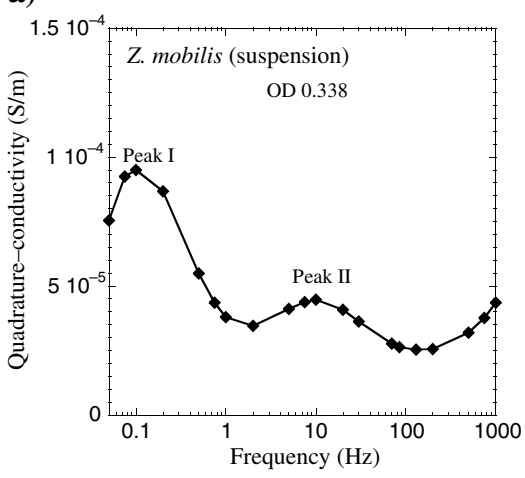

c)

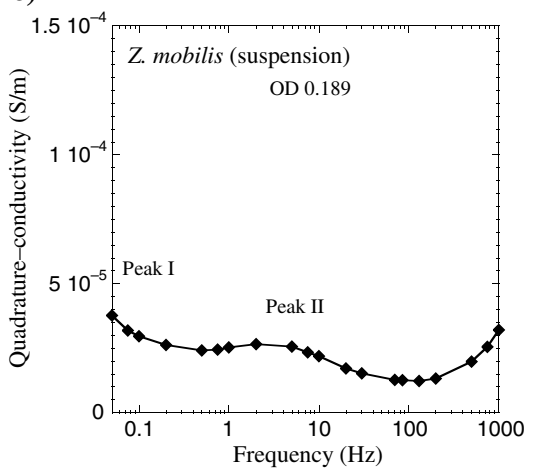

b)

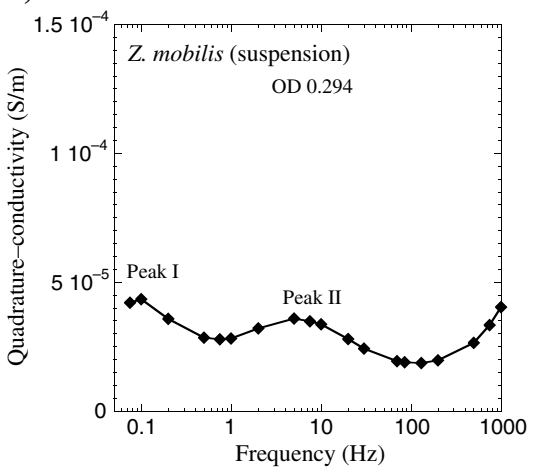

d)

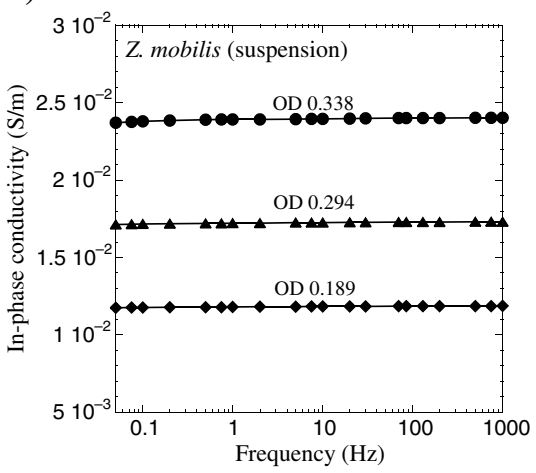

Figure 8. In-phase and quadrature conductivities for $Z$. mobilis cell suspensions at three different concentrations of bacteria ( $\mathrm{pH}$ 5.75). Quadrature conductivities for (a) OD 0.338 , (b) OD 0.294 , (c) OD 0.189, and (d) in-phase conductivity for the three bacterial densities. densities. The amplitude of the quadrature conductivity increased significantly as the cell concentration increased (Figure 8a-8c). For the bacterial suspensions, the quadrature conductivity spectra showed two distinct low-frequency dispersions: one peaking around $0.1 \mathrm{~Hz}$ (denoted as peak I in Figure 8a-8c) and a second one peaking around $5-10 \mathrm{~Hz}$ (denoted as peak II in Figure $8 \mathrm{a}-8 \mathrm{c}$ ). At about $100 \mathrm{~Hz}$, we started to see the high-frequency Maxwell-Wagner polarization (see the discussion in Revil et al., 2012a). The quadrature conductivity in the presence of bacteria (up to $\sim 9.4 \times$ $10^{-5} \mathrm{~S} \mathrm{~m}^{-1}$ for OD 0.338$)$ was significantly higher than in the case of the control experiments $\left(\sim 1.0 \times 10^{-5} \mathrm{~S} \mathrm{~m}^{-1}\right.$, see Figure $\left.7 \mathrm{~d}\right)$.

In Figure 9, we plot the quadrature conductivity of different suspensions of $Z$. mobilis versus the density of the bacterial cells estimated from the $\mathrm{OD}_{600}$ measurements (see Figure 5). Taking $F_{\mathrm{RM}}=1, \beta_{(+)}^{S}=5 \times 10^{-10} \mathrm{~m}^{2} \mathrm{~s}^{-1} \mathrm{~V}^{-1}$ at $25^{\circ} \mathrm{C}, f=0.8, \rho_{B}=$ $10^{3} \mathrm{~kg} \mathrm{~m}^{-3}$, and $\bar{V}_{B}=1.0 \mu \mathrm{m}^{3}\left(1 \times 10^{-18} \mathrm{~m}^{3}\right)$, and the observed value of $a_{S}=8.3 \times 10^{-14} \mathrm{~m} \mathrm{~S}^{-1} \mathrm{~mL} \mathrm{cell}^{-1}$ (from the slope shown in Figure 9), we can determine the value of the CEC of the bacteria given from equation 6 by

$$
\mathrm{CEC}_{B}=\frac{a_{S}}{\bar{V}_{B} \rho_{B} f \beta_{(+)}^{S}} .
$$

This yields $\mathrm{CEC}_{B}=2.1 \mathrm{mMolg}^{-1}$ (reported in Table 3). This value is consistent with the mean value for Gram-negative bacteria reported in Table 1 of Revil et al. (2012a): $\mathrm{CEC}_{B}=1.80 \mathrm{mMol} \mathrm{g}^{-1}$.

\section{Suspensions in porous media}

The quadrature and in-phase conductivities for the three different concentrations of Z. mobilis mixed with silica sand (properties summarized in Table 1) are shown in Figure 10a-10c. The in-phase conductivity increased from $0.0051 \mathrm{~S} \mathrm{~m}^{-1}$ to $0.0082 \mathrm{~S} \mathrm{~m}^{-1}$ (Figure 10d) as the OD increased from 0.189 to 0.338 . The magnitude of the quadrature conductivity was also greater for higher cell concentrations (Figure 10a-10c). We still recognize two polarization peaks, but localized at relatively lower frequencies than in the suspensions (for OD 0.338 and OD 0.294). This observation will be discussed in more detail below. Note that in Figure 10, the measurements at the lowest frequencies (below $0.05 \mathrm{~Hz}$ ) could be affected by cell lysis during the long measurement period.

The evolution of the quadrature conductivity at 0.1 and $5 \mathrm{~Hz}$ with the density of bacterial cells is shown in Figure 11a and 11b for peaks I and II, respectively. Our model predicts the following value: $a=a_{S} / F=2.2 \times 10^{-5} \mathrm{~m} \mathrm{~S}^{-1}$ using $a_{S}=8.3 \times 10^{-14} \mathrm{~m} \mathrm{~S}^{-1} \mathrm{mLcell}^{-1}$ and $F=3.7$. This value remains, however, smaller than the observed values $a_{S}=3.4 \times 10^{-14} \mathrm{~m} \mathrm{~S}^{-1} \mathrm{~mL} \mathrm{cell}^{-1}$ for peak II. A higher value is reached for peak I $\left(a_{S}=10 \times 10^{-14} \mathrm{~m} \mathrm{~S}^{-1} \mathrm{~mL}\right.$ cell $\left.{ }^{-1}\right)$. Therefore, our model fails to accurately predict the dependence of the quadrature conductivity with the density of bacteria. 


\section{DISCUSSION}

\section{Some comments regarding the experimental results}

Our model has been successful with respect to two points: (1) The CEC required to explain the experimental data is consistent with the CEC of Gram-negative bacteria and (2) the quadrature conductivity is proportional to the abundance of bacteria in the solution or in the porous material. We focus our discussion below on the effect of the porous material regarding the relationship between the quadrature conductivity and the abundance of bacteria in the pore water phase.

In Figure 12, we plot the quadrature conductivity of the colloidal suspension of Z. mobilis at OD 0.338 with and without the sand grains. The first observation is related to the presence of the two peaks in the quadrature conductivity, for the suspensions and for the suspensions in the porous materials. One possibility is that peak I corresponds to the polarization of the bacteria and peak II corresponds to the polarization of the protruding organic molecules around the bacteria themselves (Figures 1 and 2). In this case, the situation would be similar to what Leroy et al. (2008) observes for glass beads with the low-frequency peak related to the polarization of the grains and a higher frequency peak associated with the roughness of the grains (both corresponding to $\alpha$-polarization mechanisms associated with the polarization of the electric double layer). Indeed, the roughness of the grains or the protruding organic molecules around the bacteria corresponds to smaller polarizable length scales by comparison with the sand grains or the bacteria, respectively, and is therefore expected to polarize at higher frequencies. For instance, micrometer-scale heterogeneities on a glass bead produce polarization in the range $1-100 \mathrm{~Hz}$ (Leroy et al., 2008).

In Figure 12, we clearly see both a reduction in the magnitude of the amplitude of the quadrature conductivity as well as a shift toward lower frequencies (approximately a factor of four in the presence of sand). This may indicate that the diffusion coefficient in the definition of the relaxation time may need a correction by the bulk tortuosity of the pore space. Indeed, the effective diffusion coefficient of a salt or an anionic species should be corrected at the macroscale of a representative elementary volume by the tortuosity of the pore network (see Leroy et al. [2006]; see Binley et al. [2010] for the SIP problem). The bulk tortuosity also affects the surface and quadrature conductivities directly according to the model developed by Revil (2013a). We expect indeed that the pathways for the migration of the ions need to be corrected for the tortuosity effect around the grains.

Figure 13 shows the high-frequency parts of the spectra for the suspension of $Z$. mobilis. We note that the high-frequency part of the spectra is dominated by a pure dielectric constant $\varepsilon_{\infty} \approx \varepsilon_{r} \varepsilon_{0}$ where $\varepsilon_{0}$ denotes the dielectric constant of a vacuum and $\varepsilon_{r} \approx 300$ represents the relative permittivity for the suspension. This high value (compared with the relative permittivity of water $\sim 80$ ) may be due to Maxwell-Wagner polarization ( $\beta$-polarization). Because of the scaling with frequency, this polarization cannot be an $\alpha$-polarization mechanism associated with, for instance, the polarization of the electric double layer around the protruding organic molecules around the cell of the bacteria.

In Figure 14, we plot the surface conductivity versus the quadrature conductivity of $Z$. mobilis and the sand used in this study. Our results agree with the data set discussed by Weller et al. (2013) for clayey media and are consistent with the prediction of the model of

Revil (2013a, 2013b). This indicates, as suggested by Revil et al. (2012a), that the mobility of the counterions of the bacteria is very close to the mobility of the counterions for clay minerals. Using equations 2 and 3 and the data displayed in Figure 14, the ratio of the surface conductivity to the quadrature conductivity is given by

$$
\frac{\sigma_{B}^{S} \prime}{\left|\sigma_{B}{ }^{\prime \prime}\right|}=\frac{(1-f) \beta_{(+)}}{f \beta_{(+)}^{S}} \approx 23.8 .
$$

Assuming $\beta_{(+)}^{S}=5 \times 10^{-10} \mathrm{~m}^{2} \mathrm{~s}^{-1} \mathrm{~V}^{-1}$ (Revil et al., 2012a) and $\beta_{(+)}=5 \times 10^{-8} \mathrm{~m}^{2} \mathrm{~s}^{-1} \mathrm{~V}^{-1}$ (mobility of $\mathrm{Na}^{+}$in water), we obtain $f=0.81$. This probably represents the fraction of counterions located in the Stern layer ( $~ 80 \%$ in this case), in close agreement with the discussion provided by Revil et al. (2012a). Figure 14 also indicates that the surface conductivity and quadrature conductivity of Z. mobilis are on the same order of magnitude as the surface and quadrature conductivities of minerals. Additional data will be needed to confirm this finding. Therefore, only time-lapse studies can be used to decipher, in the electric signals, any changes associated with growth and decay of bacterial populations.

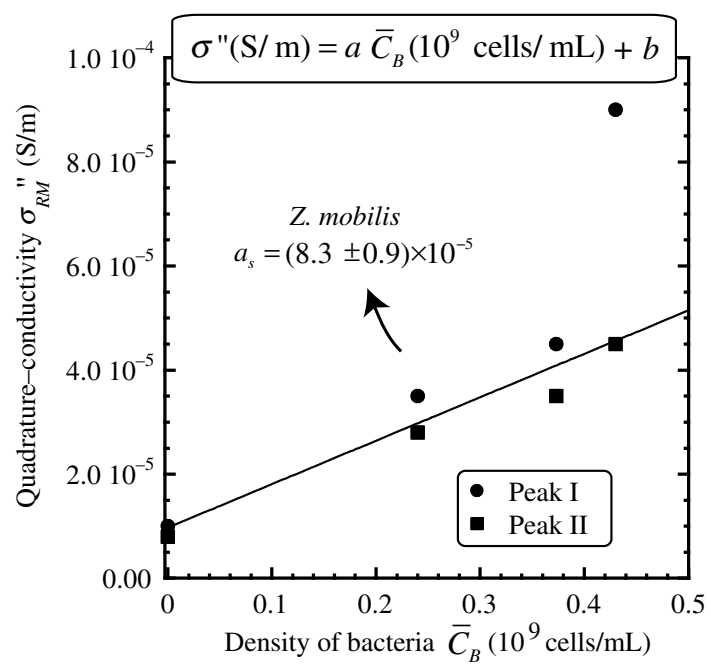

Figure 9. Quadrature conductivity versus bacteria density for different concentrations of bacteria. The data are taken at the two peak frequencies. Fitted parameters $a=(8.3 \pm 0.9) \times 10^{-5} \mathrm{~S} \mathrm{~m}^{-1}$ and $b=(1.0 \pm 0.3) \times 10^{-5} \mathrm{~S} \mathrm{~m}^{-1}\left(R^{2}=0.934\right)$.

Table 3. Properties of Z. mobilis.

Properties Z. mobilis

Stern later mobility $\beta_{(+)}^{S}$

Cation exchange capacity $\mathrm{CEC}_{B}$

Partition coefficient $f$

Mass density $\rho_{B}$

Elementary volume $\bar{V}_{B}$

$5 \times 10^{-10} \mathrm{~m}^{2} \mathrm{~s}^{-1} \mathrm{~V}^{-1}$
$2 \times 10^{5} \mathrm{C} \mathrm{kg}^{-1}$
0.8
$10^{3} \mathrm{~kg} \mathrm{~m}^{-3}$
$1.0 \mu \mathrm{m}^{3}\left(10^{-18} \mathrm{~m}^{3}\right)$




\section{Potential applications and future works}

If our goal is to understand the SIP response during the monitoring of bacterial activity in the shallow subsurface associated with remediation activities such as oil spills, then we need to understand the various contributions to the electric response. We believe that there are three major contributions to the changes observed in SIP signatures during oil biodegradation. The first is the contribution associated with the presence of the oil itself. As shown for instance by Schmutz et al. (2010), Revil et al. (2011), and Abdel Aal and Atekwana (2014), oil saturation and wettability play a central role in the SIP response of oil-bearing media. Note that the wettability of oil can change over time in an oil spill due to the formation of biopolymers that change the surface tension of oil.

The second contribution is due to the presence of bacteria. Their growth and decay can be described by Monod kinetics. Revil et al. (2012a) provide a model for this contribution (especially in the case of Gram-positive bacteria), and the present work extends this research to Gramnegative bacteria. The present work can be used to predict semiquantitatively the change in the quadrature conductivity associated with the presence of bacteria. As our data suggest, the magnitude of the quadrature conductivity increases with cell density. This provides us with a rough approximation of what we can observe in field conditions according to our model. Kostka et al. (2011) studied beach sands contaminated by the Deepwater Horizon oil spill in the Gulf Coast of Mexico. They found a concentration of oildegrading bacteria of $2.4 \times 10^{16}$ cells m$^{-3}$ $\left(24 \times 10^{9}\right.$ cells $\left.\mathrm{mL}^{-1}\right)$ in oil-contaminated sands, whereas the background concentration was on the order of 2 to $9 \times 10^{12}$ cells m$^{-3} \quad(0.02-$ $0.09 \times 10^{9}$ cells $\left.\mathrm{mL}^{-1}\right)$. Our work implies that for sand, the variation in quadrature conductivity $\Delta \sigma^{\prime \prime}$ associated with a variation in bacterial cells concentration $\Delta \bar{C}_{B}$ is given by $\Delta \sigma^{\prime \prime}=a \Delta \bar{C}_{B}$ (at $0.1 \mathrm{~Hz}$ ) with $a=10^{-4} \mathrm{~S} \mathrm{~mL} \mathrm{~m}^{-1}$ cells $^{-1}$ and with the concentration of bacteria expressed in $10^{9}$ cells $\mathrm{mL}^{-1}$. Therefore, a change in bacteria concentration of $24 \times 10^{9}$ cells $\mathrm{mL}^{-1}$ would correspond to a highly detectable change of $2.4 \times$ $10^{-3} \mathrm{~S} \mathrm{~m}^{-1}$ (at $0.1 \mathrm{~Hz}$ ) in the quadrature conductivity (assuming that the phase is greater than the detectable value of $0.5 \mathrm{mrad}$ in field conditions).

The third contribution is the one associated with the presence of semiconductors such as pyrite and magnetite that can be produced by the bacteria themselves (e.g., Mewafy et al. [2013], in the case of magnetite). Despite the fact that this contribution has been clearly demonstrated in the laboratory, challenges remain with respect to understanding its nature and the effect of the redox conditions in the pore water. Future works will be dedicated to better understanding this contribution by expanding the work of Wong (1979). The ultimate goal is to predict the SIP response of bacterial activity over time by integrating the three contributions in a unified mechanistic framework.
Figure 11. Quadrature conductivity versus the density of bacteria at (a) $0.1 \mathrm{~Hz}$ and (b) $5 \mathrm{~Hz}$ for $Z$. mobilis with sand. The data are fitted by equation 13 . The slope between the quadrature conductivity and the density of bacteria is substantially smaller than in the case of the suspension of the same bacteria in the absence of the solids (Figure 9). From the value of $b$, we have the value of the quadrature conductivity of the grains: $\sigma_{g}{ }^{\prime \prime}=$ $-0.8 \times 10^{-5} \mathrm{~S} \mathrm{~m}^{-1}$ for the sand grains.

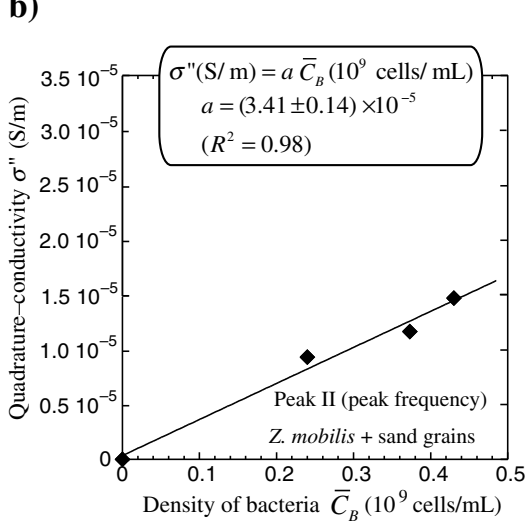




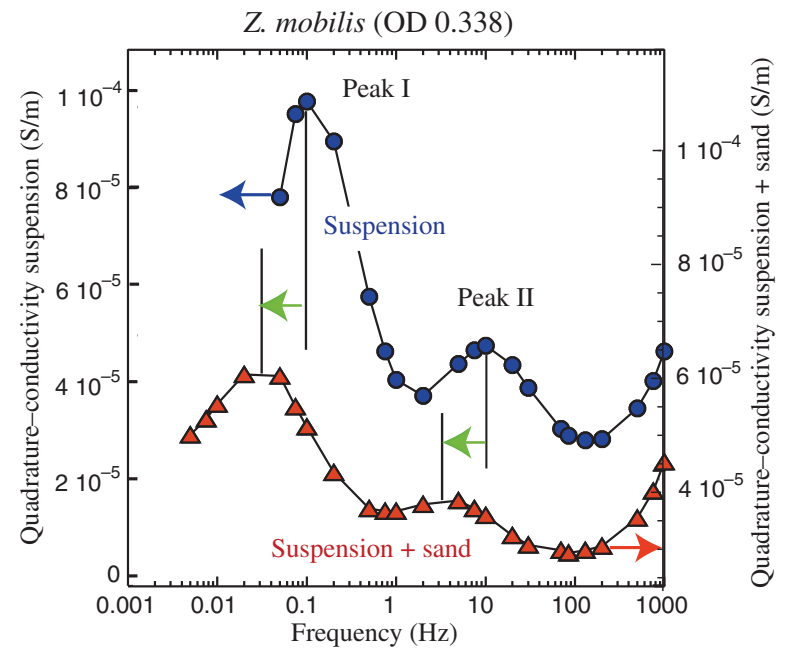

Figure 12. Comparison between the quadrature conductivity for a suspension of $Z$. mobilis (OD 0.338) with and without sand grains. The presence of the sand grains decreases the amplitude of the polarization and also displaces the polarization peaks I and II to lower frequencies (see green arrows).

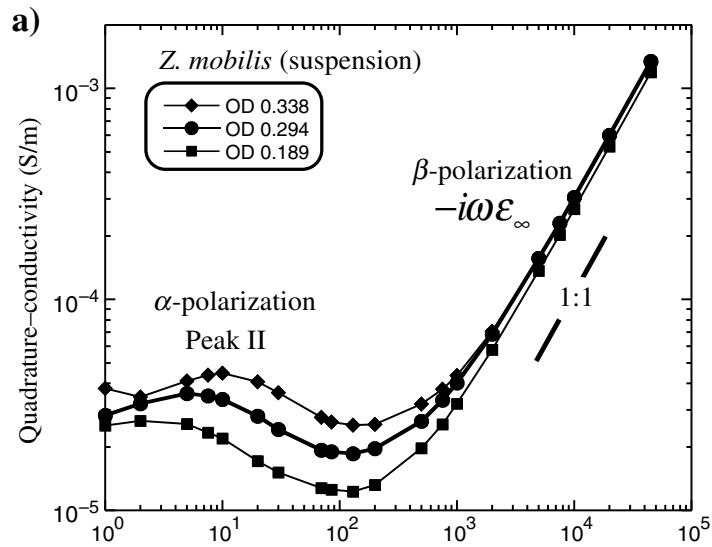

b)

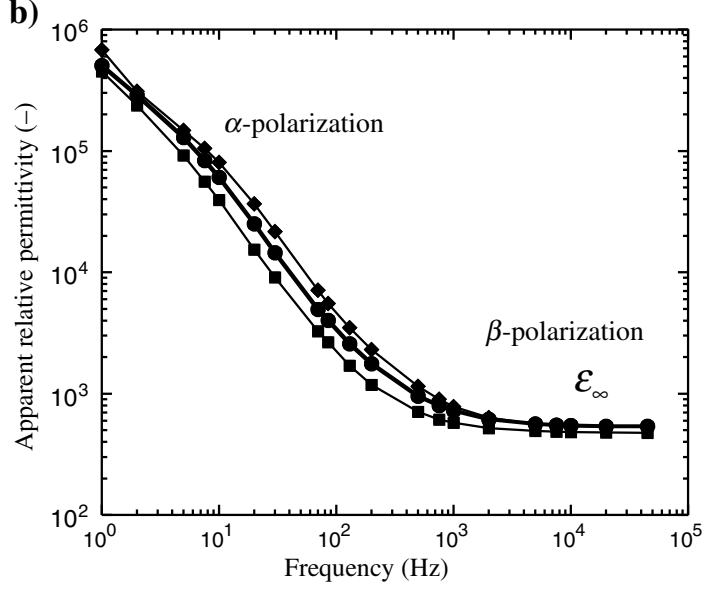

Figure 13. High-frequency part of the quadrature conductivity spectra for Z. mobilis (colloidal suspension with RM). The influence of the bacteria is clearly much smaller above $1 \mathrm{kHz}$. The $\alpha$ - and $\beta$-polarizations correspond to the polarization of the electric double layer and Maxwell-Wagner polarization, respectively.

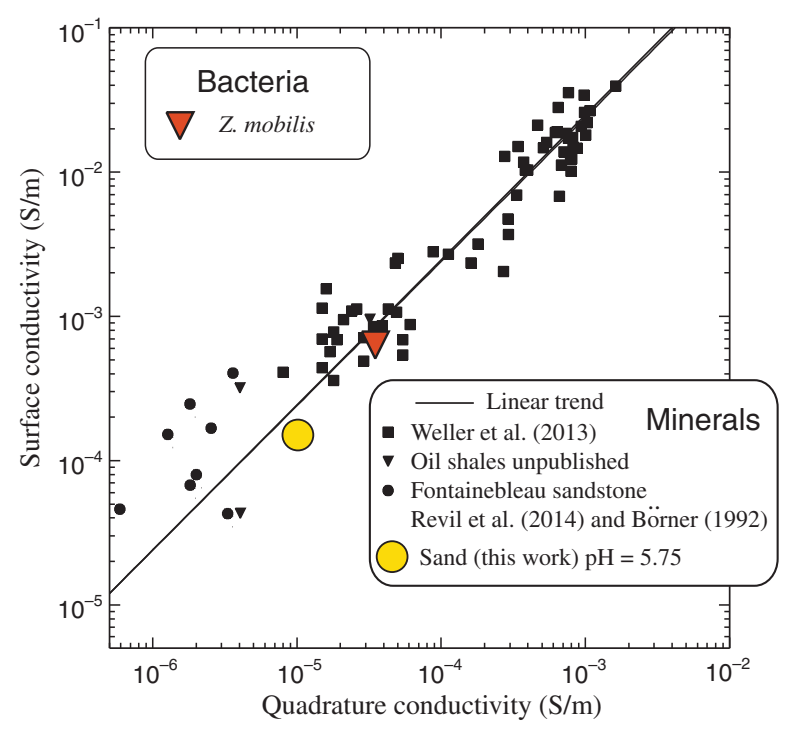

Figure 14. Comparison of the relationship determined by Weller et al. (2013) for clayey materials and additional data including oil shales with very low porosity and samples of Fontainebleau sandstones (Revil et al. [2014] and sample F3 from Börner, 1992). As discussed by Revil et al. (2012), the bacteria seem to be characterized by a low mobility for the counterions that is similar to that of clays. In both the cases, the surface conductivity was determined from the conductivity data at different salinities and the quadrature conductivity is reported at the peak frequency of peak I.

\section{CONCLUSIONS}

We have performed complex conductivity measurements using the Gram-negative bacterium Z. mobilis at different concentrations of bacterial cells. The measurements were done with suspensions of cells and by mixing these suspensions with sand grains. The following conclusions have been reached:

1) The quadrature conductivity spectra exhibit two peaks, one around $0.05-0.5 \mathrm{~Hz}$ (peak I) and another around 1-10 Hz (peak II). For peaks I and II, the experiments show that the amplitude of the quadrature conductivity depends on the density of cells for the suspensions of bacteria and the mixtures of sand with these cells.

2) The trend between the quadrature conductivity of the cell suspension and the density of the bacteria can be qualitatively reproduced with a simple polarization model of the electric double layer. However, the quantitative relationship between the quadrature conductivity and the density of bacteria in porous media in these experiments was not well predicted by our model. Further studies, e.g., with different bacteria and with different porous media, are needed to evaluate this relationship.

3) The ratio between the surface conductivity of the bacteria and their quadrature conductivity seems to be consistent with the ratio found for the minerals, indicating that the mobility of the counterions in the Stern layer is substantially smaller than the mobility of the counterions in the diffuse layer and that approximately $80 \%$ of the counterions are located in the Stern layer.

\section{ACKNOWLEDGMENTS}

This work is funded by Idaho National Laboratory Scientific Focus Area, the Office of Science, and Chevron Energy Technology 
Company (grant \#CW852844). We thank J. Henriksen for advice regarding the choice of bacterial species for the experiments and G. Abdel Aal and E. Atekwana for their comments on a previous version of the manuscript. Y. Fujita and G. Redden would also like to express their deep gratitude to the NanoGeoScience program at Copenhagen University for facilitating their contributions to the preparation of this manuscript, and especially to the National Bank of Denmark for helping to make their residence with Copenhagen University possible. We also thank the three referees for the constructive reviews and the associate editor E. Saenger for handling our manuscript.

\section{REFERENCES}

Abdel Aal, G., E. Atekwana, L. Slater, and E. Atekwana, 2004, Effects of bacterial processes on electrolytic and interfacial electrical properties of unconsolidated sediments: Geophysical Research Letters, 31, L12505doi: 10.1029/2004GL020030.

Abdel Aal, G. Z., and E. A. Atekwana, 2014, Spectral induced polarization (SIP) response of biodegraded oil in porous media: Geophysical Journal International, 196, 804-817, doi: 10.1093/gji/ggt416.

Abdel Aal, G. Z., E. A. Atekwana, S. Rossbach, and D. D. Werkema, 2010, Sensitivity of geoelectrical measurements to the presence of bacteria in porous media: Journal of Geophysical Research, 115, G03017, doi: 10 1029/2009JG001159.

Albrecht, R., J. C. Gourry, M.-O. Simonnot, and C. Leyval, 2011, Complex conductivity response to bacterial growth and biofilm formation on phenanthrene spiked medium: Journal of Applied Geophysics, 75, 558-564, doi: 10.1016/j.jappgeo.2011.09.001.

Binley, A., S. Kruschwitz, D. Lesmes, and N. Kettridge, 2010, Exploiting the temperature effects on low frequency electrical spectra of sandstone: A comparison of effective diffusion path lengths: Geophysics, 75, no. 6, A43-A46, doi: 10.1190/1.3483815.

Bolève, A., A. Crespy, A. Revil, F. Janod, and J. L. Mattiuzzo, 2007, Streaming potentials of granular media: Influence of the Dukhin and Reynolds numbers: Journal of Geophysical Research, 112, B08204, doi: 10.1029/ 2006JB004673.

Börner, F. D., 1992, Complex conductivity measurements of reservoir properties: in Chardaire-Riviere, C., and P. F. Worthington, eds., Proceedings of the Third European Core Analysis Symposium, Harwood Academic, 359-386.

Bratbak, G., and I. Dundas, 1984, Bacterial dry matter content and biomass estimations: Applied and Environmental Microbiology, 48, 755-757.

Cockett, A. R., and A. Pidlisecky, 2014, Simulated electrical conductivity response of clogging mechanisms for managed aquifer recharge: Geophysics, 79, no. 2, D81-D89, doi: 10.1190/geo2013-0054.1.

Davis, C. A., E. Atekwana, L. D. Slater, S. Rossbach, and M. R. Mormile, 2006, Bacterial growth and biofilm formation in geologic media is detected with complex conductivity measurements: Geophysical Research Letters, 33, L18403, doi: 10.1029/2006GL027312.

Eisele, T. C., and K. L. Gabby, 2014, Review of reductive leaching of iron by anaerobic bacteria: Mineral Processes and Extractive Metallurgy Review, 35, 75-105, doi: 10.1080/08827508.2012.703627.

Foster, K. R., and H. P. Schwan, 1989, Dielectric properties of tissues and biological materials: A critical review: Critical Reviews in Biomedical Engineering, 17, 25-104.

Ginn, T. R., B. D. Wood, K. E. Nelson, T. D. Scheibe, E. M. Murphy, and T. P. Clement, 2002, Processes in bacterial transport in the natural subsurface: Advances in Water Resources 25, 1017-1042, doi: 10.1016/S03091708(02)00046-5.

Grabowski, A., O. Nercessian, F. Fayolle, D. Blanchet, and C. Jeanthon, 2005, Bacterial diversity in production waters of a low-temperature biodegraded oil reservoir: FEMS Microbiology Ecology, 54, 427-443, doi: 10.1016/j.femsec.2005.05.007.

Grech, R. T., J. Cassar, K. P. Muscat, S. G. Camilleri, M. Fabri, P. Zervakis, V. Xanthopoulos, B. Sakkalis, and B. Vanrumste, 2008, Review on solving the inverse problem in EEG source analysis: Journal of NeuroEngineering and Rehabilitation, 5, 25, doi: 10.1186/1743-0003-5-25.

Grube, M., R. Rutkis, M. Gavare, Z. Lasa, I. Strazdina, N. Galinina, and U. Kalnenieks, 2012, Application of FT-IR spectroscopy for fingerprinting of Zymomonas mobilis respiratory mutants: Spectroscopy: An International Journal, 27, 581-585, doi: 10.1155/2012/163712.

Gunasekaran, P., T. Karunakaran, and M. Kasthuribai, 1986, Fermentation pattern of Zymomonas mobilis strains on different substrates - A comparative study: Journal of Bioscience, 10, 181-186, doi: 10.1007/ $\mathrm{BF} 02703475$.
Heenan, J., A. Porter, D. Ntarlagiannis, L. Young, D. Werkema, and L. Slater, 2013, Sensitivity of the spectral induced polarization method to microbial enhanced oil recovery processes: Geophysics, 78, no. 5, E261-E269, doi: 10.1190/geo2013-0085.1.

Ikard, S. J., A. Revil, A. Jardani, W. F. Woodruff, M. Parekh, and M. Mooney, 2012, Saline pulse test monitoring with the self-potential method to non-intrusively determine the velocity of the pore water in leaking areas of earth dams and embankments: Water Resources Research, 48, W04201, doi: 10.1029/2010WR010247.

Kemna, A., 2000, Tomographic inversion of complex resistivity: Dissertation, Ruhr Universität Bochum.

Kemna, A., A. Binley, G. Cassiani, E. Niederleithinger, A. Revil, L. Slater, K. H. Williams, A. Flores Orozco, A. F.-H. Haegel, A. Hördt, S. Kruschwitz, V. Leroux, K. Titov, and E. Zimmermann, 2012, An overview of the spectral induced polarization method for near-surface applications: Near Surface Geophysics, 10, 453-468, doi: 10.3997/18730604.2012027.

Kostka, J. E., O. Prakash, W. A. Overholt, S. J. Green, G. Freyer, A. Canion, and M. Huettel, 2011, Hydrocarbon-Degrading Bacteria and the Bacterial Community Response in Gulf of Mexico Beach Sands Impacted by the Deepwater Horizon Oil Spill: Applied and Environmental Microbiology, 77, no. 22, 7962-7974, doi: 10.1128/AEM.0540211.

Leroy, P., A. Revil, and D. Coelho, 2006, Diffusion of ionic species in bentonite: Journal of Colloid and Interface Science, 296, 248-255, doi: 10 .1016/j.jcis.2005.08.034.

Leroy, P., A. Revil, A. Kemna, P. Cosenza, and A. Ghorbani, 2008, Spectral induced polarization of water-saturated packs of glass beads: Journal of Colloid and Interface Science, 321, 103-117, doi: 10.1016/j.jcis.2007.12 .031 .

Linde, N., and A. Revil, 2007, Inverting self-potential data for redox potentials of contaminant plumes: Geophysical Research Letters, 34, L14302, doi: 10.1029/2007GL030084.

Mewafy, F. M., D. D. Werkema, E. A. Atekwana, L. D. Slater, G. Abdel Aal, A. Revil, and D. Ntarlagiannis, 2013, Evidence that bio-metallic mineral precipitation enhances the complex conductivity response at a hydrocarbon contaminated site: Journal of Applied Geophysics, 98, 113-123, doi: 10.1016/j.jappgeo.2013.08.011.

Naudet, V., and A. Revil, 2005, A sandbox experiment of the relationship between redox and self-potential and its application to the interpretation of self-potential data over contaminant plumes: Geophysical Research Letters, 32, L11405, doi: 10.1029/2005GL022735.

Naudet, V., A. Revil, J.-Y. Bottero, and P. Bégassat, 2003, Relationship between self-potential (SP) signals and redox conditions in contaminated groundwater: Geophysical Research Letters, 30, 2091, doi: 10.1029/ 2003GL018096.

Naudet, V., A. Revil, E. Rizzo, J.-Y. Bottero, and P. Bégassat, 2004, Groundwater redox conditions and conductivity in a contaminant plume from geoelectrical investigations: Hydrology and Earth System Sciences (HESS), 8, 8-22, doi: 10.5194/hess-8-8-2004.

Ntarlagiannis, D., K. Williams, L. Slater, and S. Hubbard, 2005b, Lowfrequency electrical response to bacterial induced sulfide precipitation: Journal of Geophysical Research, 110, G02009, doi: 10.1029/ 2005JG000024.

Ntarlagiannis, D., N. Yee, and L. Slater, 2005a, On the low-frequency electrical polarization of bacterial cells in sands: Geophysical Research Letters, 32, L24402, doi: 10.1029/2005GL024751.

Personna, Y. R., D. Ntarlagiannis, L. Slater, N. Yee, M. O'Brien, and S. Hubbard, 2008, Spectral induced polarization and electrodic potential monitoring of bacterially mediated iron sulfide transformations: Journal of Geophysical Research, 113, G02020, doi: 10.1029/2007JG000614.

Pethig, R., and G. H. Markx, 1997, Applications of dielectrophoresis in biotechnology: Trends in Biotechnology, 15, 426-432, doi: 10.1016/S01677799(97)01096-2.

Revil, A., 2013a, Effective conductivity and permittivity of unsaturated porous materials in the frequency range $1 \mathrm{mHz}-1 \mathrm{GHz}$ : Water Resources Research, 49, 306-327, doi: 10.1029/2012WR012700.

Revil, A., 2013b, On charge accumulations in heterogeneous porous materials under the influence of an electrical field: Geophysics, 78, no. 4, D271-D291, doi: 10.1190/geo2012-0503.1.

Revil, A., E. Atekwana, C. Zhang, A. Jardani, and S. Smith, 2012a, A new model for the spectral induced polarization signature of bacterial growth in porous media: Water Resources Research, 48, W09545, doi: 10.1029/ 2012WR011965.

Revil, A., M. Karaoulis, T. Johnson, and A. Kemna, 2012b, Review: Some low-frequency electrical methods for subsurface characterization and monitoring in hydrogeology: Hydrogeology Journal, 20, 617-658, doi: 10.1007/s10040-011-0819-x.

Revil, A., P. Kessouri, and C. Torres-Verdín, 2014, Electrical conductivity, induced polarization, and permeability of the Fontainebleau sandstone: Geophysics, 79, no. 5, D301-D318, doi: 10.1190/geo2014-0036.1. 
Revil, A., C. A. Mendonça, E. Atekwana, B. Kulessa, S. S. Hubbard, and K. Bolhen, 2010, Understanding biogeobatteries: Where geophysics meets microbiology: Journal of Geophysical Research, 115, G00G02, doi: 10 $.1029 / 2009$ JG001065.

Revil, A., M. Schmutz, and M. L. Batzle, 2011, Influence of oil wettability upon spectral induced polarization of oil-bearing sands: Geophysics, $\mathbf{7 6}$ no. 5, A31-A36, doi: 10.1190/geo2011-0006.1.

Revil, A., and M. Skold, 2011, Salinity dependence of spectral induced polarization in sands and sandstones: Geophysical Journal International, 187, 813-824, doi: 10.1111/j.1365-246X.2011.05181.x.

Revil, A., W. F. Woodruff, C. Torres-Verdín, and M. Prasad, 2013, Complex conductivity tensor of hydrocarbon-bearing shales and mudrocks: Geophysics, 78, no. 6, D403-D418, doi: 10.1190/geo2013-0100.1.

Risgaard-Petersen, N., L. R. Damgaard, A. Revil, and L. P. Nielsen, 2014, Mapping electron sources and sinks of microbial generated electric currents in marine sediment: Journal of Geophysical Research, doi: 10.1002/ 2014JG002673.

Risgaard-Petersen, N., A. Revil, P. Meister, and L. P. Nielsen, 2012, Sulfur, iron-, and calcium cycling associated with natural electric currents running through marine sediment: Geochimica et Cosmochimica Acta, 92, 1-13, doi: 10.1016/j.gca.2012.05.036.

Schmutz, M., A. Revil, P. Vaudelet, M. Batzle, P. Femenía Viñao, and D. D. Werkema, 2010, Influence of oil saturation upon spectral induced polarization of oil bearing sands: Geophysical Journal International, 183, 211-224 doi: 10.1111/j.1365-246X.2010.04751.x.

Toledo, F. L., C. Calvo, B. Rodelas, and J. Gonzales-Lopez, 2006, Selection and identification of bacteria isolated from waste crude oil with polycyclic aromatic hydrocarbons removal capacities: Systematic and Applied Microbiology, 29, 244-252, doi: 10.1016/j.syapm.2005.09.003.
Weller, A., L. Slater, and S. Nordsiek, 2013, On the relationship between induced polarization and surface conductivity: Implications for petrophysical interpretation of electrical measurements: Geophysics, 78, no. 5, D315-D325, doi: 10.1190/geo2013-0076.1.

Williams, K. H., D. Ntarlagiannis, L. D. Slater, A. Dohnalkova, S. S. Hubbard, and J. F. Banfield, 2005, Geophysical imaging of stimulated bacterial biomineralization: Environmental Science \& Technology, 39, 7592-7600, doi: $10.1021 / \mathrm{es} 0504035$.

Willis, M. R., 1980, Dielectric and electronic properties of biological materials, in R. Pethig, ed., Biochemical education: John Wiley \& Sons, vol. 8, 31 .

Wong, J., 1979, An electrochemical model of the induced-polarization phenomenon in disseminated sulfide ores: Geophysics, 44, 1245-1265, doi: $10.1190 / 1.1441005$.

Woodruff, W. F., A. Revil, and C. Torres-Verdín, 2014, Laboratory determination of the complex conductivity tensor of unconventional shales: Geophysics, 79, no. 5, E183-E200, doi: 10.1190/GEO20130367.1.

Zhang, C., D. Ntarlagiannis, L. Slater, and R. Doherty, 2010, Monitoring bacterial sulfate reduction in porous media using multipurpose electrodes: Journal of Geophysical Research, 115, G00G09, doi: 10.1029/ 2009 JG001157.

Zhang, C., L. Slater, and C. Prodan, 2013, Complex dielectric properties of sulfate-reducing bacteria suspensions: Geomicrobiology Journal, 30, 490-496, doi: 10.1080/01490451.2012.719997.

Zimmermann, E., A. Kemna, J. Berwix, W. Glaas, H. M. Munch, and J. A. Huisman, 2008, A high-accuracy impedance spectrometer for measuring sediments with low polarizability: Measurement Science and Technology, 19, 105603, doi: 10.1088/0957-0233/19/10/105603. 